\title{
THE VERTICAL WHEELER
}

\author{
P. E. WAKEFIELD. Dip. Phısio. (U.C.T.)*
}

\section{SUMMARY}

The revical wheeler provide's the means for independen mobilits in the standing posision. thus combibuing towards the phusical and psychological requrements of the paraplegic child.

\section{INTRODUCTION}

Independent mobility and upright posture are major requirements in the inanagement of the paraplegic child durmg his growing years. The quality of life for the physically disabled child is onhanced by providing the means for the freedom of movement he longs for and needs in order to experience and explore his environment. The psychological benefits derived from the upright posture include an improved iclf-image, potential for normal cvelevel communication and imcraction with his peers and the community. The phvsiological advantages of weightbearing in the standing position comprise the prevention of lower limb contractures and ipinal deformity decreased ostenporosis. stimulation of bone srowith. reduction of spasticity and improved urinary dralnage

In the treatment of the paraplegic chite, a great deal of cumphasis is placed on achicving the maximal degree of ambulation and minimal use of the wheelchair. However. unless the level of the neurological lesion is sufficicntly lou ambulation with the aid of calipers and crutches is frustratingly slow, requires a high level of cnergy ex penditure and the hands are not free for functional and play activities. These limilations have led to the development of the swiscl ivalker but this appliance does not provide for upeed of movement and crutches are required for outdoor lise. The vertical walker has been developed in order 10 mect boul the physical and psychological requirements of the paraplegic child. This appliance provides fast. precise. independent mobility un the standing postion.

The devclopment of the vertical whecler at the Spinal Cord Injuries Centre. Conradic Hospital. was undertaken as a ioint profect by the Physiotherapy Depariment of the Conradic Hospital and the Department of Bio-Medical Engineerin@. U.C.T. and Groote Schuur Hospital. in 1979.

\section{DESCRIPTION OF APPLIANCE}

The vertical whecler consists of a frame which holds the child ereci bv means of frol, knee. pelvis and I runk supports. These supports. which are well padded to prevent pressure sores. are fully a djustable to allow for initial fitting is well ats for subsequent growih

The frame is inounted on realr wheels and front castors and is propelled manually by pushung rims and a chain drive. which are also adjustable to the height of the user Alternatively. power-drive whecls and joystick control may be fitted 10 the frame for the more scicicly disabled child who is unablc to propel the appliance with his hands

Parking brakes are provided to ensure that the appliance remains stationary during transfer activities. The provision

*Chief Physiotherapist, Conradie Hospital, Pinclands. Received 8 April 1982.

\section{OPSOMMING}

Die remikale wiolsroel roorsion onafhanklike mobilineir in wie staande posisice wat bidra lot die fisiese en psigiese behoefe's san die parapleglese hind.

of a ripping har and hand-hold ensure casy handling for the attendant. cspccially of lhe wery young child.

The appearance of the wertical whecter is attractive to the child bi virtue of its design and bright. cheerful colour
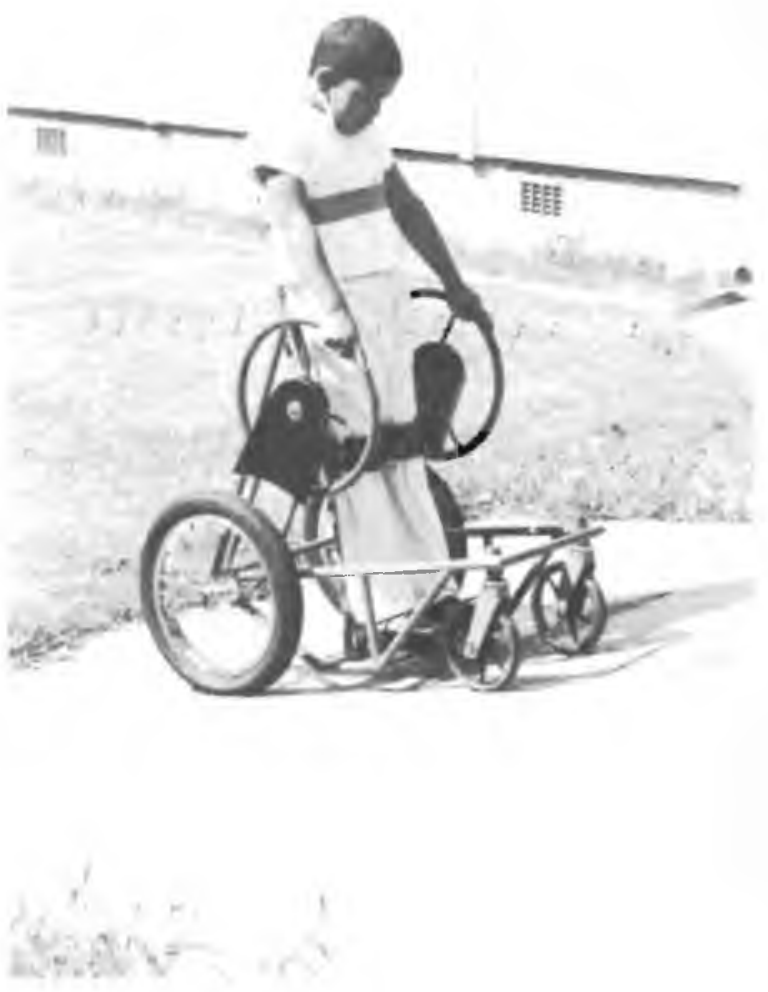

Fig. 1. Independent mobility - Shaun age 9 years, T4 complete paraplegia.

\section{DISCUSSION}

The vertical whecler has been found to be of considerable value in the rehabilitation of paraplegic children. It is clear that the appliance provides a degree of independent frecdom of movement which these children are otherwise unable to allain. whulst. smultaneously. gainng the benefits of standing

It is striking to observe the pleasure and fun the children derive from using the vertical whecler. Home and school reports indicate that the childien are more active, more alcrt and hat social funcioning is greatly improved. 


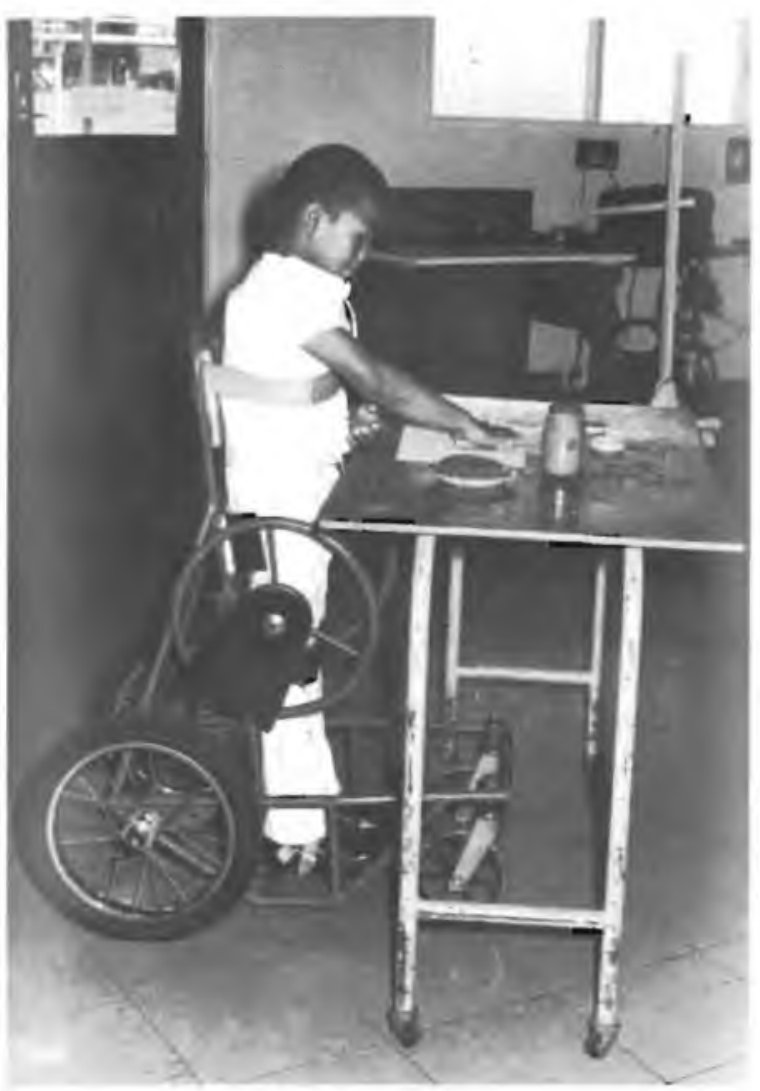

Fig. 2. Hands-free standing.

The whecler is proving to be especally effective in the prevention of jom contraclures and abnumal. encorres postures as well as unhibiting upasucuts Functuonal abilı k enhanced by secure hands-lres sanding. and upper lumb sirength as well as cardiopulmonarv litncus increased the children are able to tolerate wse of the appliance for the full period of a normal bay and no widence of lower lumb oedema has been encountered. The whecler w inherenth stable and is safe to use up and dow n voper. Apart from a few sessions lcarming how $10 \mathrm{get}$ in and out of the applance user lraining has been found to be unnecessary. The appliance is braked and lipped backward to the horizontal position for the child to transice in and out of 14 . The supports are then fastened in us us unce commencing with the feet. and by means of a monkev chann, or sımilar device. lhe child can pull himsell up to the vertical position. The ease and simplicity with which adjustment for grouth w accomplished, obviates in interrupuons in the use of the wheeler and is a saving in cost. The wheeler inulially issued willl sec a child through ho growing vears untll he reacher adulthood. at which stage the paraplege usually becomes a "sluer" in a wheclchair. Prowision hals been maje in tha design. For the frame to be extended if need be, and. In facl. the applance has been succerfullv kested by a few adult paraplegics.

Finally. although initially developed for the traumatu paraplegic. the vertical whecles has heen found useful in the managcment of the physically handicapped chuld of variou other disabilitics.

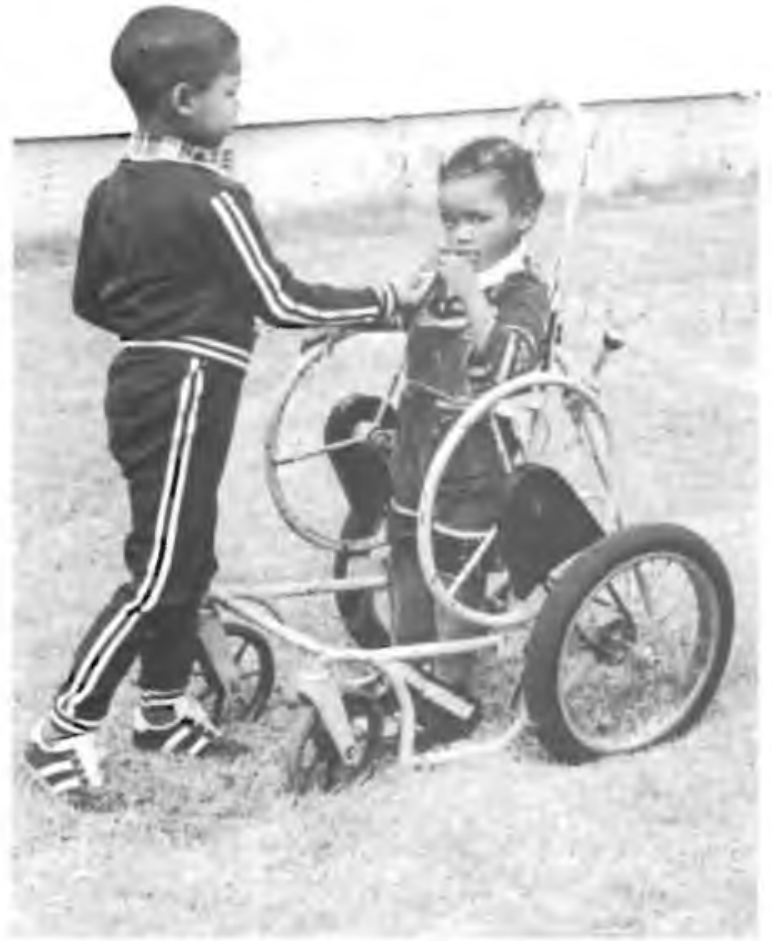

Fig. 3. Social functioning. Early model of the Vertical Wheeler. Annie, age 3 sears. Tl complete paraplegia.

\section{Bibliography}

Bedbrook, G M (1977 78). Collctian of scolious due Io

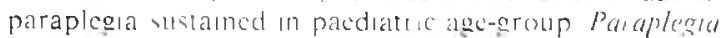
15. $90-96$

Bromles. 1. (1976) Teliaplegal and Paraplegia Chuschull Livingsion. Edumburgh

Kaplan, P E. Roden, W. Gibert. E. Richark. L . Goldschmidi, R D and John W (1981) Reduction of hypercalciuria in teliaplegld alter weight-beatume dind strenglhenung esercises. Par aplesia 19,289-29.3.

Roca, L and Hopkıns. P (1978) Swinel Walkers. Phwotherapl 64, 14-18

\section{AMENDMENT TO ETHICAL RULE 2 I (I)}

The South Atrican Medical and Dental Council hav accepted the amendment of Erhical Rulc 21 (I) Io that of "Patients will be treated on relerral from a Regutered Medical or Dental practutioner or in close co-operation with such registered practitioners" The amendment of this rulc still has 10 be passed by the Minuter of Healih and then gazetted before 11 will appli in practice. 